\title{
Video Ders Uygulaması Sınıf Ortamında Dönüt-Düzeltmeye Zaman Ayırmak İçin Etkili Bir Yol Olabilir mi?
}

\author{
Can Video-Based Course Be An Effective Way to Spare Time for Feedback- \\ Correction in the Classroom?
}

\author{
Muhittin ÇALIŞKAN ${ }^{1}$ \\ Hüseyin SERÇE ${ }^{* *}$ \\ Mevlüt AYDOĞMUŞ
}

\begin{abstract}
$\ddot{O} Z$
Bu eylem araştırmasinda "Derslerimizde öğrenciden öğretmene, öğretmenden öğrenciye bilgi aklşını sağlayabilmek ve gerekli ise düzeltme yapabilmek için nasll zaman aylrabiliriz?" sorusuna cevap arandl. Dönüt ve düzeltmeye zaman ayırmak için video ders uygulaması gerçekleştirildi. Bu uygulamada neler olduğu rapor edilmeye çalışıldı. Araştırma özel öğretim yöntemleri dersinde bu dersi alan öğrencilerle birlikte gerçekleştirildi. Uygulama sekiz hafta sürdü. Sinffta üç alandan (muhasebe ve finansman, adalet, kuyumculuk teknolojisi) ögrenciler vard. Her grup kendi alanindan bir dersin konusunu seçip video hazırladl. Her bir grubun videosunu dersten önce diğer iki grup izledi. Derste, video hazırlayan grup, video izleyen gruplara konu ile ilgili sorular sordu, cevaplara göre dönüt verdi, gerektiğinde düzeltmeler yaptı. Sürecin etkililiği hakkında öğrencilerin görüssleri yazılı olarak alındı. Ayrıca dersin sorumlu öğretim elemanı araştırma günlügü tuttu. Veriler tümevarım analizi ile analiz edildi. Araştırma sonunda, ön öğrenmelerin tam olmasl şartıyla, hazır ve kısa videoların yaşantı zenginliği sağlaması açısından dönem içerisinde bir ya da iki kez kullanılabileceği sonucuna ulaşıldl.
\end{abstract}

\section{ANAHTAR KELIMELER}

Eylem Araştırması, Öğretmen Araştırması, Dönüt, Düzeltme, Video Ders Uygulaması

\begin{abstract}
In this action research, an answer to the question of "How can we spare more time to ensure the flow of information from student to teacher and teacher to student, and to make corrections if necessary? Accordingly, a video-based course was implemented to dedicate more time for feedback and correction in the classroom. Therefore, it was reported here what happened in this implementation. The study was conducted with university students taking the course "special teaching methods". The implementation lasted eight weeks. The students were from three different fields (accounting and finance, jurisprudence, and jewellery technology). Each group chose a topic of a lesson in their field and prepared a video. The other two groups watched the video of each group before coming to class. During the lesson, the group who made the video asked questions to the other groups who had already watched it, gave feedback according to the answers, and made corrections when necessary. The opinions of the students about the effectiveness of the process were collected in a written way. In addition, the lecturer responsible for the course kept a research diary. The data was analyzed through an inductive approach. At the end of the research, it was concluded that if the prior knowledge of the students is complete, short and readily available videos can be used once or twice in the course period in order to provide richness of experience.
\end{abstract}

\section{KEYWORDS}

Action Research, Teacher Research, Feedback, Correction, Video-based Course

\begin{tabular}{|c|c|c|}
\hline \multicolumn{2}{|r|}{$\begin{array}{c}\text { Makale Geliş Tarihi / Submission Date } \\
11.10 .2019\end{array}$} & $\begin{array}{c}\text { Makale Kabul Tarihi / Date of Acceptance } \\
\text { 07.11.2019 }\end{array}$ \\
\hline Atıf & $\begin{array}{l}\text { Çalışkan, M., Serçe H. ve Aydoğmuş, } \\
\text { Ayırmak İçin Etkili Bir Yol Olabilir n } \\
\text { 991-998. }\end{array}$ & $\begin{array}{l}\text { Uygulaması Sınıf Ortamında Dönüt-Düzeltmeye Zaman } \\
\text { i Sosyal Bilimler Meslek Yüksekokulu Dergisi, } 22 \text { (2), }\end{array}$ \\
\hline
\end{tabular}

\footnotetext{
${ }^{1}$ Doç. Dr., Necmettin Erbakan Üniversitesi, mcaliskan@erbakan.edu.tr, ORCID: 0000-0002-2341-0710

${ }^{* *}$ Dr. Öğr. Üyesi., Selçuk Üniversitesi, hserce@selcuk.edu.tr, ORCID: 0000-0001-7132-2910

*** Dr. Öğr. Üyesi., Necmettin Erbakan Üniversitesi, maydogmus@erbakan.edu.tr, ORCID: 0000-0003-1286-2970
} 


\section{GIIRIŞ}

Bir öğretim sonunda amaca ulaşılması yani öğrenmenin gerçekleşmesi birçok değişkene bağlidır. Bu değişkenlerden bazıları öğrenenle ilgili, bazıları da ona sunulan hizmetin niteliği ile ilgilidir. Bloom (1998), bu değişkenlerden öğrenme düzeyi üzerinde diğerlerine göre daha önemli bir etkiye sahip olan ve müdahale edilebilen değişkenleri belirlemiştir. Bunlar; öğrenci nitelikleri (bilişsel giriş davranışları ve duyuşsal giriş özelikleri) ile öğretim hizmetinin niteliğidir. Öğrenci nitelikleri olumlu hale getirildiğinde ve buna ek olarak öğretim hizmetinin niteliği iyileştirildiğinde öğrenme düzeyi yükselmektedir.

Öğretim hizmetinin niteliğini belirleyen değişkenler ipucu, katılma, pekiştirme ve dönüt-düzeltmedir (Bloom, 1998). Bir eğitim durumunda dönütün yönlendirici, güdüleyici ve pekiştirici olmak üzere üç temel işgörüsü olduğu yani dönüt verilirken ipucu, düzeltme ve pekiştireçlerin bir arada işe koşulabileceği (Sönmez, 2012, s. 153) düşünüldüğünde dönütün öğretim hizmetinin niteliğini belirleyen değişkenler içinde öne çıtı̆̆g söylenebilir. Dönüt, denemelik davranışın (Denemelik davranış demek daha uygun olabilir.) doğruluğu, yanlışlığı, yanlış ise eksiklik ve aksaklıkların neler olduğu, eksiklik ve aksaklıkların nasıl giderilebileceği konularında sağlanan iletiler bütünüdür. Düzeltme ise dönüt işlemleri ile belirlenen eksiklik ve yetersizliklerin giderilmesi amacıyla yapılan işlemlerin tümüdür (Bloom, 1998). Dönüt ve düzeltme, grupla öğrenmede öğretim hizmeti niteliğini ve öğrenme düzeyini belirleyen en önemli öğedir (Senemoğlu, 2013, s. 455). Sinıfta her öğrenciye ihtiyacını karşılayacak derecede iyi bir öğretim niteliği sağlanmış olmasını güvence altına almak için dönüt ve düzeltme işlemlerinden yararlanılması gerekir (Bloom, 1984; Demirel, 1994). Grupla öğrenme durumlarında, öğreticinin, işaret ve açıklamalar, pekiştirme, katılma önlemlerinin bazı öğrencilerin bunlarla ilgili ihtiyaçlarını tam karşılayamaması yüzünden meydana gelmiş olabilecek öğrenme eksikliklerinden ve güçlüklerden anında haberdar olmasını ve bu aksaklıkları zamanında gidermesini sağlayacak önlemlere gerek duyulmaktadır. Dönüt ve düzeltme işte bu tür önlemleri sağlar (Özçelik, 1998, s.123).

Meta-analiz çalışmaların bulguları "etkili dönütün nitelikli öğretimin önemli bir öğesi olduğu” düşüncesini doğrulamıştır (Rowe ve Wood, 2011). Alanyazında, öğrencilerin dönüt beklentisi içinde olduğu, daha çok dönüt beklentisi içinde olan öğrencilerin genellikle diğerlerinden daha başarılı olduğu ve başarılı olarak tanınan öğrencilerin dönüt beklentisi konusunda diğerlerinden farklılık gösterdiği (Alavi ve Kaivanpanah, 2007) belirtilmektedir. Diğer taraftan olumlu dönüt ve düzeltme davranışlarının çok az öğretmen tarafindan yerine getirildiği (Oral, 2000), dönüt-düzeltme etkinliklerinin ara sıra gerçekleştirildiği (Şahin, 2014) vurgulanmaktadır. Yeterli dönüt sağlanamamasının nedenleri olarak da sınıfların kalabalık olması (Karatay, 2011; Oral, 2000) ve görsel-işitsel araçların yeterli olmaması gösterilmektedir (Oral, 2000).

Etkili bir öğretim için anında dönüt verilmelidir. Araştırmalar anında verilen dönütün geciktirilmiş dönütten (Erbaş ve Yücesoy, 2002; Van der Kleij, Eggen, Timmers ve Veldkamp, 2012) daha etkili olduğunu göstermektedir. Genel olarak kullanılan not, alıştırma kitapları, kısa sınavlar, ev ödevleri gibi dönüt verme yöntemleri görev tamamlandıktan sonra verilen dönütlerdir. Bu tür dönütler sadece sonuç bilgisi verir, sürece değil ürüne odaklıdır. Dönüt, görev tamamlandıktan sonra verildiğinde, iş işten geçmiş olmaktadır. Bu nedenle görev tamamlandıktan sonra verilen dönütler dışında anında ve öğrenme sürecine rehberlik edebilecek dönüt verme yolları aranmalıdır. İşte problem de tam burada karşımıza çıkmaktadır. Dönüt verebilmek için önce öğrencinin öğrendiklerini göstermesi gerekmektedir. Dönüt, öğrenciden öğretmene, öğretmenden öğrenciye bilgi akışıdır (Özçelik, 1998, s. 194). Sınıftaki her bir öğrencinin öğrendiklerini göstermesi mümkün olmadığına göre sınıf ortamında her bir öğrenciye dönüt vermek oldukça güçtür. Bunun için zaman kalmamaktadır.

Bizler eğitim fakültesinde görev yapan öğretim elemanlarıyı. Dönüt ve düzeltme yapmadan etkili bir öğretimin-öğrenmenin gerçekleşmeyeceğinin farkındayız, bunu biliyoruz. Ama derslerimizde öğrencilere yeterince dönüt veremiyoruz ve düzeltme yapamıyoruz. Dönüt ve düzeltme yaptığımızda bu sadece birkaç öğrenci ve sadece dönütle sinırlı kalıyor. Çünkü dersimizin 5-10 dakikasını bu işlemler için ancak ayırabiliyoruz. Birkaç öğrenciye dönüt verebilsek bile düzeltme için zaman kalmıyor. Bu nedenle, bu eylem araştırmasında bizler, "Derslerimizde öğrenciden öğretmene, öğretmenden öğrenciye bilgi akışını sağlayabilmek ve gerekli ise düzeltme yapabilmek için nasıl zaman ayırabiliriz?” sorusuna odaklandık. Araştırma, birinci yazarının fakültede okuttuğu özel öğretim yöntemleri dersini alan öğrencilerle birlikte yürütüldü. İlk olarak öğrencilere öğretme-öğrenme sürecinde dönütün önemi ifade edildi. Daha sonra öğrencilerle birlikte "Anında dönüt-düzeltme için nasıl zaman ayırabiliriz?” sorusuna cevap arandı. Aşağıda yapılan literatür taramasının bir özeti verilmiştir.

Çalışkan (2015), "etkili dönüt verme yolları" adlı çalışmasında, öğrenene anında dönüt sağlayabilecek yolları aramıştır. Literatür taraması sonucunda beş tür dönüt verme yaklaşımının çalışmanın amacına uygun olduğunu bulmuştur. Bunlar; izleme testleri, programlı öğretim, akran dönütü, bilgisayar destekli dönüt verme 
ve kendi kendine dönüt verme yaklaşımlarıdır. Çalışkan (2015), bu yaklaşımlardan her birinin üstün olduğu durumlar ve sınırlı1ıklarının olduğu, sınıftaki her bir öğrencinin öğrenmesini göstermesine olanak olmadığına göre kendini izleme ve dönüt verme becerilerinin öğretilmesinin ön plana çıtığı sonucuna ulaşmıştır.

Okumuş ve Yurdakul (2016) tarafından yapılan çalışmada öncelikle öğrenciler kendi yaptıkları mikro öğretim çalışmalarının videolarını araştırmacıların kurmuş olduğu Facebook grubuna yüklemişlerdir. Daha sonra sınıf arkadaşlarından oluşan Facebook grubunun üyeleri bu videolara yorum yapmışlardır. Katılımcılar uygulama ile ilgili olumlu görüş bildirmişler ve akranlarının videolara yaptıkları yorumların hatalarını görme ve düzeltmelerinde yardımcı olduğunu ve arkadaşlarının videolarını seyrederek farklı öğretim yöntem ve teknikleriyle ilgili farkındalıklarının geliştiğini, yorum ve eleştirilerle yaptıkları işe kendilerini daha çok adadıklarını ifade etmişlerdir.

Lewis, Moore ve Nang (2015) tarafindan yapılan çalışma iletişim ve yutma güçlüğü olan çocuklar ve yetişkinler ile çalışacak kişilere eğitim veren Edith Cowan Üniversitesi'nde konuşma patolojisi bölümü lisans öğrencileri ile gerçekleştirilmiştir. Öğrencilerden klinik uygulamaları esnasında hastaları ile ilgilendikleri sırada videolar çekmeleri istenmiş ve daha sonra çektikleri videoda becerilerini en iyi gösterebilecekleri iki dakikalık bölümü almaları ve derste grup etkinliğinde arkadaşlarına sunmaları istenmiştir. Videoyu izleyen grup üyeleri performansının olumlu yönlerini ifade etmişler ve kendi iyi uygulamaları ile ilişkilendirmişlerdir.

Kısa literatür taramasından sonra öğrencilerle birlikte derste dönüt ve düzeltmeye zaman ayırmak için video ders uygulamasına karar verildi. Yani, dersten önce dersin videosu izlenecek, derste sadece dönüt ve düzeltme etkinlikleri yapılacaktı. Bu uygulamanın etkiliğini değerlendirmek için araştırma sorusu şu şekilde belirlendi: Dönüt ve düzeltmeye zaman ayırmak için uygulanan video ders uygulamasında neler oldu?

\section{YÖNTEM}

$\mathrm{Bu}$ araştırma bir eylem araştırmasıdır. Eylem araştırması, kişinin kendi öğretim uygulamalarının sistematik bir gözlemidir. Amaç belirli bir okulda ve/veya sinıfta olup bitenleri anlamaktır (Johnson, 2015, s. 128). Eylem araştırmacıları sağlam genellemeler aramaktansa, kendilerini de kişisel olarak dâhil oldukları, belirli bir durumun koşullarını değiştirmelerini sağlayacak bilgiyi elde etmeye yoğunlaşırlar (Büyüköztürk, Kılıç Çakmak, Akgün, Karadeniz ve Demirel, 2011, s. 18). Eylem araştırması eğitimsel problemleri çözme ve gelişim kaydetmeye yönelik sistematik bir süreçtir. Bu eylem araştırmasında da video ders uygulamasının dönüt ve düzeltmeye zaman ayırmada etkililiği gözlenmeye çalışılmıştır.

\subsection{Katılımcilar}

Çalışma bir eğitim fakültesinde pedagojik formasyon programında özel öğretim yöntemleri dersini alan bir sınıftaki öğrencilerle birlikte gerçekleştirildi. Sınıfta üç farklı bölümden 21 öğrenci vardı. Öğrencilerin bölümlere ve cinsiyete göre dağılımı Tablo 1'de gösterilmiştir.

Tablo 1: Öğrencilerin Bölümlere ve Cinsiyete Göre Dağılımı

\begin{tabular}{lccc}
\hline \multicolumn{1}{c}{ Bölüm } & \multicolumn{2}{c}{ Cinsiyet } & \\
& Kiz & Erkek & Toplam \\
Adalet & 5 & 2 & 7 \\
Kuyumculuk Teknolojisi & 5 & 3 & 8 \\
Muhasebe ve Finansman & 5 & 1 & 6 \\
Toplam & 15 & 6 & 21 \\
\hline
\end{tabular}

\subsection{Veri Toplama Araçları}

Araştırmada veriler öğrenci görüşlerinin yazılı olarak alınması yoluyla toplandı. Öğrencilerin, uygulamanın, dönüt-düzeltme etkinliklerine zaman kalması açısından etkililiğini ve genel olarak etkililiğini değerlendirmeleri istendi. Ayrıca dersin sorumlu öğretim elemanı araştırma günlüğü (Johnson, 2015) tuttu.

\section{3. İşlemler}

Araştırma 8 hafta sürdü. İlk hafta, derste, dönüt ve düzeltmenin önemi ele alındı. Sınıf ortamında dönüt verebilmek için önce öğrencinin öğrendiği davranışı göstermesi gerektiği, her bir öğrenci için bunun mümkün olmadığı, sonuç olarak dönüt ve düzeltme işlemleri için zaman ayırmanın zor olduğu vurgulandı. Daha sonra öğrencilerle birlikte "Anında dönüt-düzeltme için nasıl zaman ayırabiliriz?" sorusuna cevap arandı. Araştırma için sonraki derse kadar zaman tanındı. Öğrencilerle birlikte sorumlu öğretim elemanı da araştırma yaptı. Yapılan kısa literatür taraması sonunda ikinci hafta şu karara varıldı: Dersten önce konunun videosunun 
izlenmesi, derste sadece dönüt ve düzeltmelere yer verilmesi. Video hazırlayabilmeleri için öğrencilere iki hafta verildi. Sınıfta üç alandan (Adalet - Kuyumculuk Teknolojisi - Muhasebe ve Finansman) öğrenciler vardı. Her grup kendi alanında liselerde okutulan bir dersin konusunu seçip video hazırladı. Kuyumculuk teknolojisi ögrencileri takı çizimi ve üretimi dersinin isim kesme konusunda 28 dakika süren bir video hazırladı. Adalet öğrencilerinin 44 dakika süren videoları hukuk dili ve terminolojisi dersinin toplumsal hayatı düzenleyen kurallar konusunda idi. Muhasebe ve finansman öğrencileri temel muhasebe dersinin sosyal güvenlik işlemleri konusunda 35 dakika süren bir video hazırladı. Beşinci hafta planlama yapıldı. Bu planlamaya göre altıncı haftanın dersine kadar adalet ve muhasebe-finansman öğrencileri kuyumculuk teknolojisi öğrencilerinin hazırlamış olduğu videoyu izleyip konuyu öğreneceklerdi. Derste ise sadece dönüt ve düzeltme etkinlikleri yapılacaktı. Altıncı hafta adalet ve muhasebe-finansman öğrencileri kuyumculuk teknolojisi öğrencilerinin hazırlamış olduğu videoyu izleyerek derse geldiler. Derste kuyumculuk öğrencileri diğer öğrencilere kısa bir çoktan seçmeli sınav uyguladılar. Sınavdaki sorular isim kesme işleminde kullanılan araç ve gereçlerin adını, hangi amaçla kullanıldığını ve bu araç-gereçleri kullanırken nelere dikkat edilmesi gerektiği bilgilerini ölçen sorulardı. Her bir sorunun cevabı tek tek okundu. Yanlış yapanlara gerekli açıklamalar yapıldı. Soru-cevap şeklinde ders tamamlandı. Yedinci ve sekizinci hafta sirasıyla adalet ve muhasebe-finansman öğrencilerinin videolarını diğer gruplar izledi ve derste aynı etkinlikler yapıldı. Her hafta sorumlu öğretim elemanı araştırma günlüğüne notlar aldı. Son hafta ise sürecin etkililiği hakkında öğrenci görüşleri alındı. Araştırmada gerçekleştirilen işlemler Şekil 1'de özetlenmiştir.

\section{Şekil 1: Araştırmada Gerçekleştirilen İşlemler}

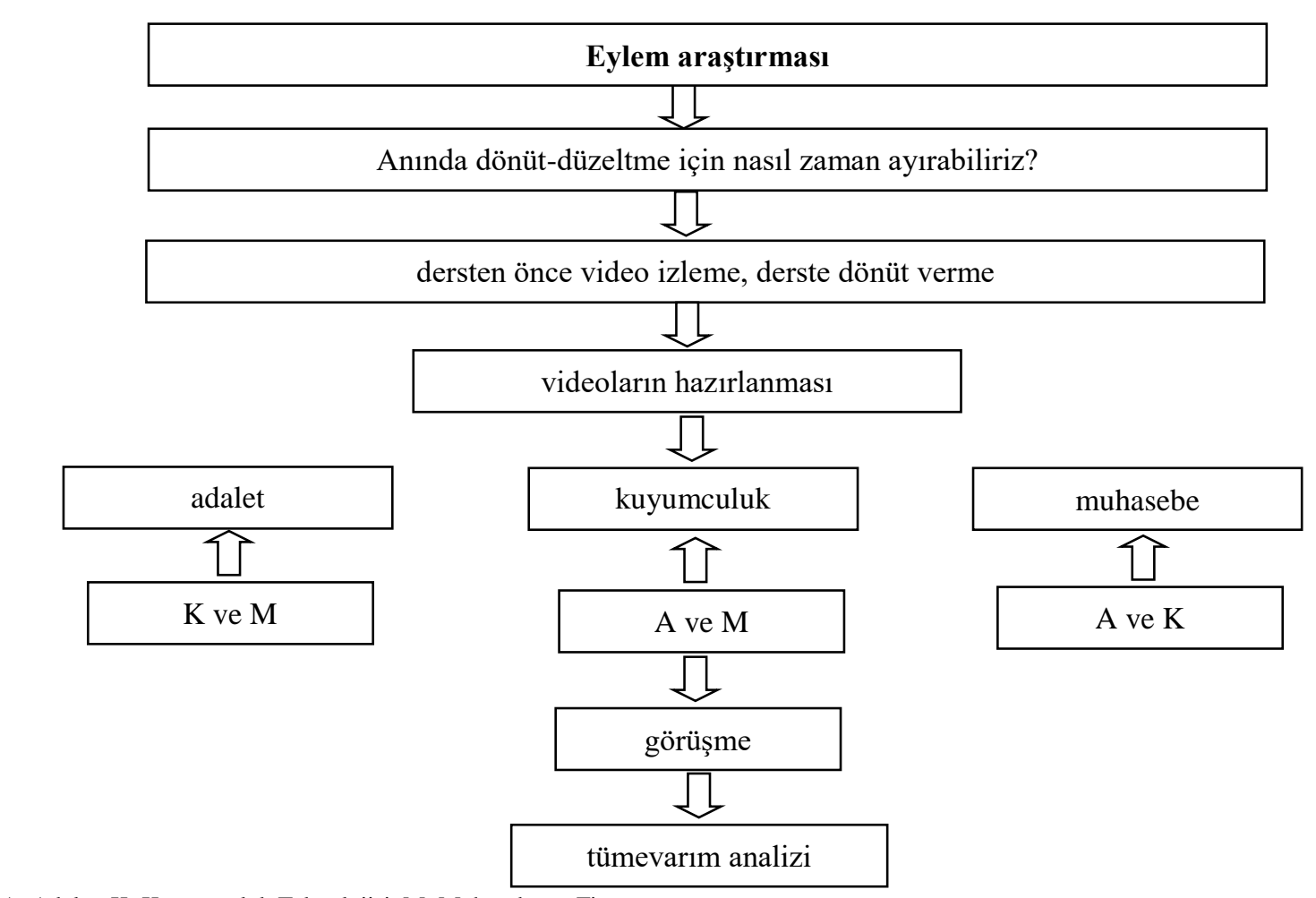

A: Adalet, K: Kuyumculuk Teknolojisi, M: Muhasebe ve Finansman

\subsection{Verilerin Analizi}

Hem öğrenci görüşlerinden hem de araştırma günlüğünden elde edilen veriler tümevarım analizi (Johnson, 2015) ile analiz edildi. Öğrenci görüşlerinden elde edilen verilerin analizinde görüşler düzenlendi, temalar ya da ortaya çıkan örüntüler arandı. Bunu yapabilmek için öncelikle neyin arandığına bir ölçüt oluşturması için soru belirlendi. Bu soru şuydu: "Öğrenci görüşlerinde uygulamanın etkililiğine atıf yapan ifadeler nelerdir?" $\mathrm{Bu}$ soru 1 şı̆ğında başlangıç kategorileri oluşturuldu. Yinelenen analizlerde bu kategoriler netleşti. İki araştırmacı ayrı ayrı analiz etti. Benzer şeyler kodlandı ve kategorilere taşındı. Böylelikle beş ana kategori ve yirmi iki alt kategori oluşturuldu. Araştırma günlüğündeki verilerin analizinde ise günlükteki notlar okundu, uygulamanın etkililiğine atıf yapan notlar belirlendi.

\section{BULGULAR}

Öğrenci görüşlerinin analizinden elde edilen kategoriler ve alt kategoriler Tablo 2'de verilmiştir. 
Tablo 2: Öğrenci Görüşlerinin Tümevarım Analizi Sonuçları

\begin{tabular}{|c|c|}
\hline kategoriler ve alt kategoriler & $\mathbf{f}$ \\
\hline genel değerlendirme & 5 \\
\hline kullanılabilir bir yöntem & 3 \\
\hline genel olarak başarılı bir etkinlik oldu & 1 \\
\hline ara sira kullanılırsa etkili olabilir & 1 \\
\hline dönüt ve düzeltme & 8 \\
\hline dönüt ve düzeltme için zaman kalıyor & 4 \\
\hline dönüt vermede etkili & 4 \\
\hline avantajlar & 17 \\
\hline istediğim zaman, istediğim yerde, istediğim kadar izleyebilmem çok iyi & 6 \\
\hline tekrar tekrar izleme firsatı sunuyor & 5 \\
\hline ön bilgileri tamamlamak için kullanılabilir & 2 \\
\hline derse hazırlıklı gelmeyi sağlıyor & 1 \\
\hline mesleki dersler için uygun olabilir & 1 \\
\hline $\begin{array}{l}\text { öğretmen kendini izleyip, birebir değerlendirme yapıp, düzeltme yapabiliyor (öğretmen kendine } \\
\text { dönüt sağlıyor) }\end{array}$ & 1 \\
\hline öğretmen kendini daha rahat ifade edebiliyor & 1 \\
\hline sinırlılıklar & 17 \\
\hline video hazırlamak zor ve zaman alıcı & 7 \\
\hline önbilgiler tam değilse yöntem yetersiz kalabilir & 4 \\
\hline elinin altında olduğu için erteleme & 1 \\
\hline diştan denetimli bireyler izlemeyebilir & 1 \\
\hline sürekli kullanılamaz & 1 \\
\hline sayısal derslerde etkili olmayabilir & 1 \\
\hline $\begin{array}{l}\text { dersin doğal akışı olmadığından tahmin yapmak zor, her şey ayrıntılı anlatılmak zorunda kalıyor, bu } \\
\text { da video süresini uzatıyor }\end{array}$ & 1 \\
\hline sorularımızı hemen soramıyoruz & 1 \\
\hline öneriler & 5 \\
\hline dikkatin dağılmaması için videonun süresi uzun olmamalı & 4 \\
\hline video hazırlama konusunda eğitim alınmalı & 1 \\
\hline
\end{tabular}

Tablo 2 incelendiğinde, öğrencilerin, uygulamanın daha çok avantajlarına ve sınırılıklarına atıf yaptıkları görülmektedir. Hazırlanan ders videolarının, derse gelmeden, "istenilen zaman, istenilen yerde, istenilen kadar izlenebilmesi" ve "tekrar tekrar izlenilebilmesi" avantajlar alt kategorisinin ilk sıralarında yer almaktadır. Bu kategoride dikkati çeken bir görüş, bu uygulamada "öğretmenin de kendine dönüt sağlayabileceği”" görüşüdür. Sınırlılıklar kategorisinin ilk sıralarında "video hazırlamanın zor ve zaman alıcı" olduğu görüşü gelmektedir. İkinci sırada ise "ön bilgiler tam değilse yöntemin yetersiz kalabileceği" görüşü yer almaktadır. Her ne kadar en son sıralarda yer alsalar da "dersin doğal akışı olmadığından tahmin yapmak zor, her şey ayrıntılı anlatılmak zorunda kalıyor, bu da video süresini uzatıyor" ve "sorularımızı hemen soramıyoruz" görüşleri dikkat çekmektedir. Öğrencilerin, uygulamanın, dönüt ve düzeltme açısından etkililiğine beklenenden az atıf yapmaları dikkat çekicidir. Bu kategoride, öğrenciler, böyle bir uygulamada "dönüt ve düzeltme için zaman kaldığını" ve uygulamanın "dönüt verme açısından etkili olduğunu" ifade etmişlerdir. Bunlara ek olarak, öğrenciler, genel değerlendirme kategorisinde bu uygulamanın "kullanılabilir bir yöntem olduğunu" belirtmişler ve "dikkatin dağılmaması için videonun süresinin uzun olmaması" şeklinde öneride bulunmuşlardır.

Araştırma günlüğünden elde edilen bulgular Tablo 3'de gösterilmiştir. 
Tablo 3: Öğrenci Görüşlerinin Tümevarım Analizi Sonuçları

\begin{tabular}{l}
\hline kategoriler ve alt kategoriler \\
\hline dönüt ve düzeltme \\
\hline dönüt ve düzeltme için zaman kalıyor. \\
\hline farklı uygulamalarla dönüt ve düzeltme işlemleri gerçekleştirildi. \\
\hline sınırlılıklar \\
\hline video hazırlamada bazı güçlükler gözlemlendi. \\
\hline sayıları az da olsa video izlemeyen öğrenciler vardı. \\
\hline
\end{tabular}

Araştırma günlüğünden elde edilen bulgulara göre, bu uygulamada dönüt ve düzeltme için zaman kalmaktadır. Bu zamanda farklı dönüt ve düzeltme işlemleri (soru-cevap, sınavlar vb.) gerçekleştirilmiştir. Ancak video hazırlamanın güçlükleri vardır. Öğrenci ifadelerine göre bu güçlükler çok zaman alması, bir hata yapıldığında başa dönülmesi gerektiği ve teknolojik bilgi ve beceri eksikliği şeklinde sıralanabilir. Ayrıca sayıları az da olsa videoları izlemeden derse gelen öğrenciler vardır.

\section{TARTIŞMA, SONUÇ VE ÖNERILER}

Bu çalışmada bir eğitim fakültesinde pedagojik formasyon programında özel öğretim yöntemleri dersini alan bir sınıftaki öğrencilerle birlikte "Anında dönüt-düzeltme için nasıl zaman ayırabiliriz?" sorusuna cevap aradık. Derse gelmeden önce dersin videosu izlenirse derste dönüt-düzeltme için zaman kalacağını düşündük. Bu düşünceyi uygulamaya geçirdik. Bu şekilde araştırma sorumuzu şu şekilde belirledik: Dönüt ve düzeltmeye zaman ayırmak için uygulanan video ders uygulamasında neler oldu? Veriler öğrenci görüşlerinden ve araştırma günlüğünden elde edildi.

Araştırmada özetle şu bulgulara ulaştık: Bu uygulamada dönüt ve düzeltme için zaman kalmaktadır. Uygulama dönüt alma ve verme (öğrenciden öğretmene ve öğretmenden öğrenciye) açısından etkilidir. Hazırlanan ders videolarının, derse gelmeden, "istenilen zaman, istenilen yerde, istenilen kadar izlenebilmesi" ve "tekrar tekrar izlenilebilmesi" uygulamanın avantajlarıdır. Video hazırlamak zor ve zaman alıcıdır. Ön bilgiler tam değilse yöntem yetersiz kalabilir. Dikkatin dağılmaması için videonun süresi uzun olmamalıdır. Sayıları az da olsa videoları izlemeden derse gelen öğrenciler vardır. Öğrencilerin, uygulamanın, dönüt ve düzeltme açısından etkililiğine az atıf yapmaları dikkat çekicidir. Öğrenciler daha çok uygulamanın genel olarak avantajlarına ve sınırlılıklarına atıf yapmışlardır.

$\mathrm{Bu}$ uygulamada, dersin videosu derse gelmeden izlendiğinden ve derste sadece dönüt düzeltme yapıldığından, öğrencilerin böyle bu uygulamayla ilgili olarak "Dönüt ve düzeltme için zaman ayrılabiliyor.", "Uygulama dönüt alma ve verme açısından etkilidir." ve "Zamandan ve mekândan bağımsız tekrar tekrar izleyebiliyorum." şeklinde görüş bildirmeleri beklenilen bulgulardır. Video hazırlamanın zor ve zaman alıcı olduğunun hem öğrenci görüşlerinde ifade edilmesi hem de araştırmacının gözlemlemesi bizim için önemli bir bulgudur. Şöyle ki, öğretmenin dersi ile ilgili (dersin tamamının) videolar hazırlaması kulağa hoş geliyor. Ancak bu çok zaman alıyorsa ve bazı güçlükleri varsa bu durumda ekonomiklik ilkesi ile çelişiriz. Bilindiği gibi eğitim durumlarının düzenlenmesinde ekonomiklik ilkesi de dikkate alınmalıdır. Öğrenciler "Ön bilgiler tam değilse yöntem yetersiz kalabilir." şeklinde görüş bildirmişlerdir. Bu görüşün nedeni, öğrencilerin kendileri için yeni olan alanlardaki derslerin konularına yönelik video izlemeleri olabilir. Örneğin, Adalet ve Muhasebe-Finansman öğrencileri takı çizimi ve üretimi dersinin isim kesme konusunda bir videoyu ilk kez izliyordu. Bu nedenle böyle bir bulgu bu çalışmaya özgü olabilir. Ama yine de dikkate alınması gereken bir bulgu olduğu düşünüyoruz. Öğrencilerden "uygulamanın, dönüt ve düzeltme etkinliklerine zaman kalması açısından etkililiğini ve genel olarak etkililiğini değerlendirmeleri” istenmişti. Öğrenciler, uygulamanın avantaj ve sınırlılıklarına, görüşlerinde daha çok yer vermişlerdi. Dönüt ve düzeltme açısından etkililiğine daha az atıf yapmışlardı. Bu sonuç, öğrencilerin daha çok video çekim sürecine odaklanmalarıyla açıklanabilir. Video hazırlama, grup çalışmaları, karşılaşılan güçlükler onların zihnini daha çok meşgul etmiş olabilir. Böylelikle uygulamanın dönüt düzeltme açısından etkililiği gölgede kalmış olabilir.

Bizler bu tecrübeden sonra bu uygulamayı sinıfimızda uygular mıyı? Uygularsak nasıl uygularız? Bu tecrübeden sonra ulaştığımız sonuç bir başka ifade ile inanmaya başladığımız şey şudur: Böyle bir çalışmada dönüt ve düzeltme için zaman kalmaktadır. Ancak eğitim durumlarının niteliğini belirleyen bir değişkene, öneminden dolayı, zaman ayırmak için diğer değişkenleri feda etmiş oluyoruz. Eğitim durumlarının niteliğini belirleyen dört değişken vardı. Katılım, ipucu, pekiştireç, dönüt ve düzeltme. Bu uygulamada dönüt ve düzeltme garanti altına alınıyor ama diğer üç değişken saf dışı bırakılıyor. Öğretim hizmetini nitelikli yapacağız derken başka problemlerin ortaya çıkmasına neden olabiliriz. "Dıştan denetimli bireyler 
izlemeyebilir.", "Videoyu izleme sürekli ertelenebilir." ve "Sorularımızı hemen soramıyoruz." gibi öğrenci görüşleri diğer üç değişkenin önemine atıf yapmaktadır ve bu sonucumuzu desteklemektedir. Sonuç olarak, böyle bir uygulamanın, öğrencilerin ön bilgilerinin tam olduğu konularda hazır ve kısa videoların yaşantı zenginliği sağlaması açısından dönem içerisinde birkaç kez kullanılabileceğini söyleyebiliriz.

$\mathrm{Bu}$ araştırmanın en önemli sınırlılığı, öğrencilerin öğretmen ve öğrenci rolüne girmeleridir. Şöyle ki, örneğin, kuyumculuk teknolojisi öğrencileri öğretmen olduklarını hayal ettiler, lisede kuyumculuk teknolojisi okutulan bir dersin videosunu hazırladılar, adalet ve muhasebe-finansman öğrencileri kuyumculuk bölümünde okuyan lise öğrencileri rolüne büründüler. Bu araştırmayı, bir kuyumculuk teknolojisi öğretmeni kendi sınıfında uygulasaydı, belki daha farklı bulgulara ve sonuçlara ulaşılabilirdi. Bu nedenle, bu araştırmanın, gerçek sınıf ortamlarında uygulanması önerilir. 


\section{KAYNAKÇA}

Alavi, S. M. ve Kaivanpanah, S. (2007). Feedback expectancy and EFL learners' achievement in English. Journal of Theory and Practice in Education, 3(2), 181-196.

Bloom, B. S. (1984). The search for methods of group instruction as effective as one-to-one tutoring. Educational Leadership, 41(8), 4-17.

Bloom, B. S. (1998). İnsan nitelikleri ve okulda öğrenme (D. A. Özçelik, Çev.). İstanbul: MEB Yayınları.

Büyüköztürk, Ş., Kılıç Çakmak, E., Akgün, Ö. E., Karadeniz, Ş. ve Demirel, F. (2011). Bilimsel araştırma yöntemleri (9. bs.). Ankara: Pegem.

Çalışkan, M. (2015). Etkili dönüt verme yolları. Turkish Studies - International Periodical for Languages, Literature and History of Turkish or Turkic, 10(11), 417-730.

Demirel, Ö. (1994). Genel öğretim yöntemleri (2. bs.). Ankara: USEM Yayınları.

Erbaş, D. ve Yücesoy, Ş. (2002). Özel eğitim öğretmenliği programında yer alan uygulama derslerini yürütürken kullanılan iki farklı dönüt verme yönteminin karşılaştırılması. Anadolu Üniversitesi Sosyal Bilimler Dergisi, 2(1), 109-120.

Johnson, A. P. (2015). Eylem araştırması el kitabı (Y. Uzuner ve M. Atay, Çev.) (2. bs.). Ankara: Anı Yayıncılık.

Karatay, H. (2011). 4+1 planlı yazma ve değerlendirme modelinin öğretmen adaylarının yazılı anlatım tutumlarını ve yazma becerilerini geliştirmeye etkisi. Turkish Studies - International Periodical for Languages, Literature and History of Turkish or Turkic, 6(13), 1029-1047.

Lewis, A., Moore, C. ve Nang, C. (2015). Using video of student-client interactions to engage students in reflection and peer review. Journal of University Teaching \& Learning Practice, 12(4), 1-18.

Okumuş, K. ve Yurdakal, İ . (2016). Peer feedback through SNSs (Social Networking Sites): Pre-Service teachers' views about using Facebook for peer feedback on microteachings. İlköğretim Online, 15(4), 1206-1216.

Oral, B. (2000). Öğretmen adaylarının algılarına göre ilköğretim sınıf öğretmenlerinin dönüt ve düzeltme davranışları. Eğitim Araştırmaları, 2, 59-64.

Özçelik, D. A. (1998). Eğitim programları ve öğretim. Ankara: ÖSYM Yayınları.

Senemoğlu, N. (2013). Gelişim, öğrenme ve öğretim kuramdan uygulamaya. Ankara: Yargı Yayınevi.

Sönmez, V. (2012). Program geliştirmede öğretmen el kitabı (17. bs.). Ankara: Anı Yayıncılık.

Şahin, M. (2014). Üniversite öğretim elemanlarının sınıf içi öğretimsel davranışlarına yönelik öğrenci görüşlerinin incelenmesi (Çankırı Karatekin Üniversitesi örneği). Turkish Studies - International Periodical for Languages, Literature and History of Turkish or Turkic, 9(11), 499-515.

Tomal, D. R. (2010). Action research for education (2. bs). Lanham, MD: Rowman \& Littlefield Publishers, Inc.

Rowe, A. D. ve Wood, L. N. (2011). What feedback do students want?, $<$ https://www.aare.edu.au/data/publications/2007/row07086.pdf>, [Erişim tarihi: 23.05.2018].

Van der Kleij, F. M., Eggen, T. J. H. M., Timmers, C. F. ve Veldkamp, B. P. (2012). Effects of feedback in a computerbased assessment for learning. Computer \& Education, 58, 263-272. 